\section{Coffee break}

\section{紙の発生から普及まで(18)}

\author{
伊藤通弘
}

\section{8. 紙の製法の発見}

前述したように，1930 年代以来，前漢時代に作ら れたとみられる各種の古紙片が, 中国各地で発見され, 蔡倫が紙の発明者であるという伝承を否定するような 資料が提示されてきた。最初の灞橋紙が出土した当時 は，これを前漢時代の紙と認めないとしたり，あるい は単なる麻ボロ切れに過ぎないのではないかとする意 見も多く，その後の前漢紙片の発見が続いた後まで， 長い間, 製紙術を発見したのは蔡倫であったとする考 えを持ち続ける人達もかなりあった。しかし，最近の 放馬灘紙や㦟泉紙の出土によって, 紙は前漢時代に既 に造られていたことは, 間違いのない事実とありつつ ある。

紙が蔡倫の発明であるとした，5世紀に書かれた 『後漢書』の大部分の史料は『東観漢記』から採られ ている。後漢の垣帝の元嘉元年（151）に完成した, 「蔡倫伝」を含む『東観漢記』は, 宋代までに大部分 が散冕したが, 隋代の『北堂書鈔』, 唐代の『芸文類 衆』などには, 『東観漢記』「蔡倫伝」を引用して, い ずれも「黄門の蔡倫が尚方を典作して紙をつくったの が, いわゆる蔡倫紙である」としている。ここで, 「典」は「主管する」ことで，意味は「蔡倫が尚方を 主管して紙をつくった」ということになり，『後漢書』 という「造意」(発明の意) とは書かれていない。蔡 倫は, 当時, 尚方令を兼任しており, 尚方でつくった 紙を朝廷に献じて, これが普及し, 蔡倫が候に封ぜら れた後, 尚方でつくった紙が所謂「蔡倫紙」と称され たと考えられる。

次に, 紙は最初に, どのようにして造られたか考え てみたい。先に述べた『説文解字』に書かれたように， 紙を生糸・絮でつくることは, 動物性蛋白質からなる 繊維分子間には水素結合が生じないため, 絮紙は存在 しない。しかし, 綿・絮をつくる過程が, 紙をつくる 考えの系川になったことは, 否定できない。段玉裁に よる『説文解字注』には,「製紙は漂絮から眆（はじ） まる。その初めは系・絮でこれをつくり，笘（す）で 荐（すきかさ）放てできあがる」と述べている。「眆 まる」を啓発を受けると解し, 系・絮を麻系に置き替
えると,これが最初の製紙の発端になったことが理解 できる。中国では，世界で最も早く㔻糸が発明され， 殷代には既にかなり技術も進んでいた。良質の系や絹 をつくるために, まず藏が選別され, 良い藏から系を 紡ぎ，上等の絹織物を織つた。悪い荋からは，絮をつ くり，劣つた綿材料をつくつた。(綿は細い系をつな いで, 絹布をつくること) 綿・絮をつくる時は, 悪い 蔽を草木の扊汁の湯気で募て, 数日間水に浸し, 膠質 を取り去り，さらに開いて，漂洗（洗いながらたた く)する。

絮を漂（みずでたた）き，綿をつくる過程が生んだ 纎維原料を草木の灰汁で蒸募し, 水に浸して膠質を取 って，その他の夾雑物を除いて，かなり純粋な纎維を つくるという技術的な過程と,さらに繊維の束を含む 繊維原料を水に浸し, 器具で叮解して分散させる過程 は，今日，製紙において，それぞれ蒸募および叮解と 呼ばれる重要な工程である。また, 糸・絮を竹筐の内 において, 水中で漂洗する時, 筐の上に残った絮のか すをさらして乾燥してから取り出すと薄い紙状の一片 ができるが, 纎維間の結合力がないので, 紙にはなら ない。しかしこれが植物纎維であれば，そのまま紙に なり，これは製紙における抄紙の工程に相当する。

以上のことから，糸・絮を処理する過程が麻などの 植物纎維の離解に試用された時, 初めて紙の製法が見 出されたと考えられる。こうして，さらに書写材料に 適した紙の製法に工夫がなされ，紙の品質も改善され ていったと思われる。最初の紙は細い麻系を用いた可 能性が高いことを藩吉星氏は指摘している。そして, 間もなくぼろ麻布, 麻の縄切れなどの廃物の麻原料を 用いて, ソーダで煮た後, 力をいれて吒くと, かなり 純粋の纎維が得られ良い紙ができることが発見された。

(注)

\section{韓信と漂母}

前漢の劉邦（漢の高祖）が秦を倒して建国した時に 功績のあった韓信（前 196 年没）は, 若いころ尾羽打 ちからし，悪童たちのいじめにあって股くぐりをした ことは有名な話である。淮水のほとりで釣をしていた ころ，見かねた一人の「漂母」が飯を食わせた。それ が数十日も続いたという。漂母とは, 水で絮を打って さらしていた老婆のことである。のちに楚王に封ぜら れたとき，彼はその漂母を探し出して千金を与えたこ とが『史記』に記されている。『史記』には，「諸母漂 す」と書かれ，川岸に何人もの老婆が並び，世間話で もしながら, 絮を打っていたのであろう。そんな作業 のなかから「紙」が生まれたと思われる。 